\title{
偏心補剛された H 形鋼圧縮部材の必要補剛岡性と必要補剛耐力 STIFFNESS AND STRENGTH OF REQUIRED LATERAL SUPPORT FOR H-SHAPED COMPRESSION MEMBER WITH ECCENTRIC BRACING
}

\author{
木 村祥裕*1, 小河利行*2, 正岡典夫*3, 山下哲 郎*4 \\ Yoshihiro KIMURA, Toshiyuki OGAWA, Norio MASAOKA \\ and Tetsuo YAMASHITA
}

\begin{abstract}
The previous paper clarified the demands of lateral stiffness and rotational stiffness for the eccentrical lateral support to prevent the flexural buckling of the compression member. The required properties for the lateral support is not only the stiffness but also the strength, and especially, for the eccentrical lateral support, both of the lateral strength and bending strength are required. This paper evaluates the strength demand equivalent to immovable lateral supports, and the inelastic large deformation analysis and the loading test of compression are performed to confirms the effect of the eccentrical support.
\end{abstract}

Keywords : Eccentrical Support, Demand of Lateral Strength, Demand of Bending Moment Strength, Lateral Torsional Buckling, Flexural Buckling

偏心補剛, 必要水平補剛力, 必要補剛曲げ耐力, 曲げ㨝れ座屈, 曲げ座屈

\section{1. 序}

圧縮部材に対する補剛強度に関しては，数多くの研究がなされて おり，その知見は文献1)に整理されている。これらの多くは圧縮部 材中央における中心補剛に関する研究である。実際の構造物では， 圧縮部材に对して補剛材が偏心して取り付く場合も考之られること から，偏心補剛された圧縮部材の座屈性状及び補剛材性能に関する 研究1) 4)もなされている。既往の研究では, 補剛材の取り付き位置, 補剛剛性及び補剛強度について数值解析及び載荷実験により詳細に 検討されているが, これらの研究における「偏心補剛」とは圧縮部・ 材の材長方向に対するものである。

一方, $\mathrm{H}$ 形鋼部材で構成された単層卜ラス架構の力学性状に関す る研究らがなされており，近年このような単層卜ラス架構の施工例 がいくつか報告されている。このような単層卜ラス架構において， 母屋材等の二次部材と主材である圧縮部材との接合は断面偏心とな るものの, これらの接合部が圧縮部材の座屈変形により二次部材に 生じる軸力・曲げモーメントを伝達できる十分な剛性・強度を有し ていれば，補剛材としての活用も考えられる。また，架構が $\mathrm{H}$ 形鋼 で構成され，二次部材が断面内で偏心して取り付く場合，以形鋼管 のような閉断面では問題とならない㨭れ座屈や曲げ座屈を生じる可 能性がある。

そこで，文献6）では，部材中央に配置された補剛材が断面内で偏 心補剛された場合の $\mathrm{H}$ 形鋼圧縮部材の座屈荷重と補剛材の軸剛 性・曲げ剛性との関係を明らかにした。偏心補剛の場合, 座屈モー ドが横曲げ変形だけでなく，㨝れ変形を生じることから，補剛材に
要求される剛性は圧縮部材の横変形に対する水平剛性; 及び厰れ変

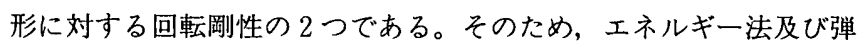
性固有值解析により, 圧縮部材の座屈荷重及び座屈変形を拘束する ために必要な水平補剛剛性, 回転補剛剛性を示した。しかし, 圧縮 部材の座屈変形が十分に拘束され; 所定の座屈荷重が確保されるた めに補剛材に要求される力学性能は剛性と強度である。そのため, 偏心補剛の場合, 圧縮部材の横変形に対する水平補剛力と㨝れ変形 に対する補剛曲げ耐力を明らかにする必要がある。

本研究では，部材中央に配置した補剛材が断面内で偏心補剛され た中幅 $\mathrm{H}$ 形鋼部材に中心圧縮荷重が作用する場合に, 文献6)で示し た必要剛性を有する補剛材に作用する水平力・曲げモーメントを明 らかにする。有限要素法による弾塑性大変形解析により, 補剛材に 必要な水平耐力・曲げ耐力を提示するとともに, 載荷実験を行い, 補剛材が圧縮部材に直交して偏心接合した場合の座屈性状及び補剛 材に作用する応力を調べ, 数值解析で示した必要水平補剛力・必要 補剛曲げ耐力を検証する。

\section{2. 偏心補剛された $\mathrm{H}$ 形鋼圧縮部材の必要水平補剛力・必要補剛 モーメント}

本章では, 必要水平補剛剛性・必要曲げ剛性を有する補剛材が $\mathrm{H}$ 形鋼圧縮部材中央に断面内で偏心して取り付く場合を想定してい る。圧縮部材が曲げ座屈するときに補剛材に作用する軸力・曲げ モーメントを調べ, 補剛材により十分な座屈拘束効果を得るために 必要な水平補剛力・補剛曲げ耐力を提示する。

\footnotetext{
*1 長崎大学工学部構造工学科 助教授・博士 (工学)

*2 東京工業大学大学院建築学専攻 教授·工博

*3 侏巴コーポレーション鉄構設計部 博士 (工学)

*4 侏巴コーポレーション技術開発部 博士(工学)
}

Assoc. Prof., Dept. of Structural Eng., Faculty of Eng., Nagasaki University, Dr. Eng.

Prof., Dept. of Architecture, Graduate School of Tokyo Institute of Technology, Dr. Eng.

Steel Structure Engineering Division, Tomoe Corporation, Dr. Eng.

Engineering Development Division, Tomoe Corporation, Dr. Eng. 


\section{1 数值解析概要}

図 1 に数值解析モデルを示す。数值解析は有限要素法汎用プロク ラムABAQUS 5.87による弾塑性大変形解析である。圧縮部材のフ ランジ, ウェブを 4 節点シェル要素, 補剛材をバネ要素としている。 部材中央にスティフナを設け，ウェブの局所的な曲げ変形を拘束し ており，バネ要素と圧縮部材を剛体要素で連結している。補剛点は， 図 2 に示すように圧縮部材の断面中心 $O$ から偏心量 $e$ に位置して いる。圧縮部材の断面は $\mathrm{H}-200 \times 100 \times 5.5 \times 8$ である。圧縮部材の材 端支持条件は，断面中心でピンローラー支持としており，材端部の 断面に剛体要素を付与している。弱軸回りの回転をピン支持, 強軸 回りの回転及び捱れ・反りを固定としている。材料特性は次章の引 張試験結果をモデル化しており，図中に示す通りである。圧縮部材 の座屈荷重に対する初期不整は， $\sin$ 半波形が最も大きな影響を与 えることが明らかにされている8)。また，文献6)では，偏心補剛され た圧縮部材において，卓越する座屈モ一ドが補剛材に作用する軸 力・曲げモーメントの大きさに影響を与えることを明らかにしてい る。すなわち，座屈変形が一次モ一ド型である( $\sin$ 半波形のような 部材中央で最大変形となる）場合，圧縮部材の荷重の増加に伴い, 補剛材に作用する水平力・モーメントは増大し，二次モード型（ $\sin$ 一波形のような部材中央で変形が生じない点対称型の変形）に移行 すると，補剛材に作用する水平力・モーメントは頭打ちになる。そ こで，本章では初期不整形状は図 2 に示すような補剛位置で最大と なる $\sin$ 半波形とし, 不整量は文献9)と同様, 現実的な範囲で圧縮部 材に最も厳しい条件となるように設定した。(1)式，(2)式に示すよう に, 図 1 の $y$ 方向に最大值が部材長の $\left(i_{y} / 20+l / 1000\right)$ となる $\sin$ 半波 の横変形と, $x$ 軸回りに材長方向に最大ねじれ角が $\left(i_{y} / 20+l / 1000\right) /$ $(d / 2)$ となる $\sin$ 半波の捩れ変形の合成波とする。

$$
\begin{aligned}
& u=\left(i_{y} / 20+l / 1000\right) \sin \frac{\pi x}{l} \\
& \beta_{0}=\tan ^{-1}(2 u / d)
\end{aligned}
$$

ここで， $d$ は図 2 に示寸ようなフランジ中心間距離であり，梁せ い $h$ からフランジ厚 $t_{f}$ を引いた値である。

\section{2 偏心補剛された $\mathrm{H}$ 形龬圧縮部材の必要補剛水平力・必要補剛 モーメント}

部材中央の補剛位置において水平変形が完全に拘束されている場合 文献6)における必要最小回転補剛剛性 $K_{\beta 0}$ は, 偏心補剛された $\mathrm{H}$ 形鋼圧縮部材中央の補剛位置において水平変形が完全に拘束されて いる場合の剛性と定義されており，次式のように示される。

$$
K_{\beta 0}=\frac{3}{8}\left(\frac{\pi}{l}\right)^{4} E I_{y} l\left(4 e^{2}+d^{2}\right)-\frac{1}{2}\left(\frac{\pi}{l}\right)^{2} G K l
$$

本論文では，必要最小回転補剛剛性 $K_{\beta 0}$ の $1 ， 2 ， 3 ， 4 ， 5$, 10倍の回転補剛剛性を有する部材について，数値解析を行った。

図3(a)(b)に偏心量 $e$ をパラメー夕として補剛材に作用するモー メント・我平力と補剛回転剛性との関係を示している。補剛点にお ける水平変位を固定としている。圧縮部材の細長比 $\lambda(=l / i)$ を 120 とし, 偏心量 $e$ を梁せい $h$ で除した偏心率 $e / h=0.5,1.0,1.5$ とし ている。(a)の縦軸は補剛材に作用するモーメント $M$ を, 数值解析よ ク得られた圧縮部材の最大耐力 $P_{m}$ に偏心量 $e$ を乗じたもので除し た補剛モーメント比 $M /\left(e \cdot P_{m}\right)$ である。(b)の縦軸は補剛材に作用す る水平力 $F$ を圧縮部材の最大耐力 $P_{m}$ で除した水平補剛力比 $F / P_{m}$

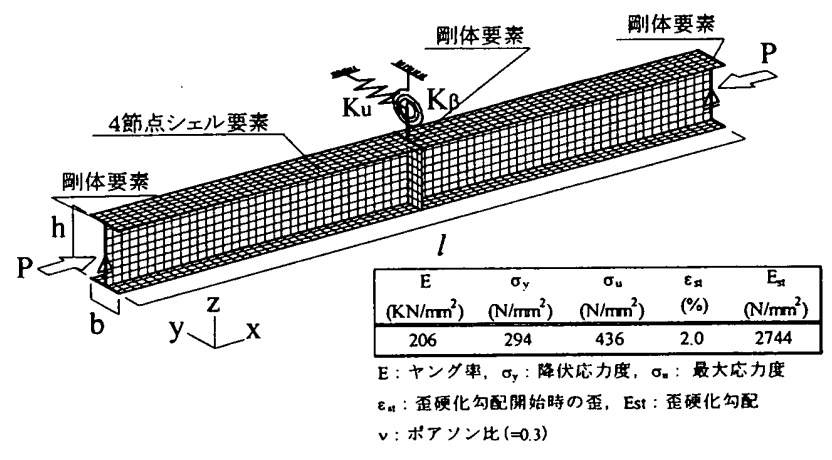

图 1 数值解析モデル及び材料特性

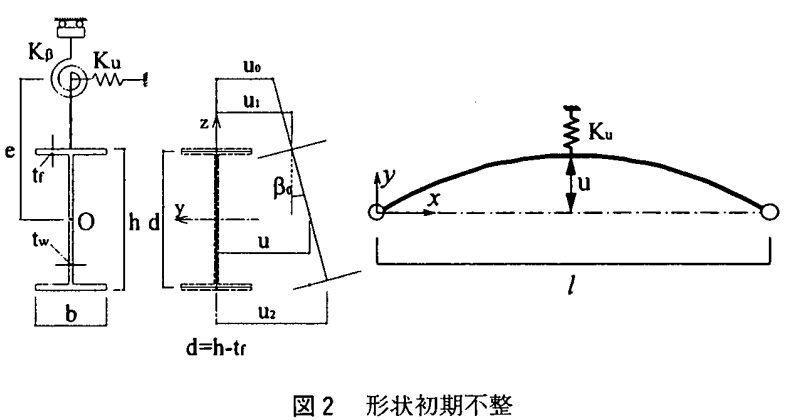

である。(a)(b)ともに百分率で表している。横軸は回転補剛剛性比 $K_{\beta} / K_{p 0}$ である。補剛材の水平力，モーメントは圧縮部材の最大耐力時の值 を用いている。回転補剛剛性比 $K_{\beta} / K_{\beta 0}$ が小さく, 偏心量が大きいほ ど補剛曲げモーメントは大きくなっており, $K_{\beta} / K_{\beta 0}=1, e / h=1.5$ の 場合，圧縮部材最大耐力時で $3.5 \%$ となっている。しかし，補剛点で 水平変位が固定されている場合, 水平補剛力は偏心量の違いによら ず概ね等しく, 回転補剛剛性比が小さいほど水平補剛力は大きく なっている。

図 $4(\mathrm{a})(\mathrm{b})$ に圧縮部材の細長比 $\lambda$ をパラメータとして，必要補剛曲 げモーメントと補剛回転剛性との関係を示す。偏心率 $e / h$ は 1.0 で

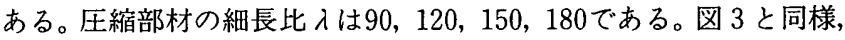
回転補剛剛性比が小さいほど補剛モーメント・補剛力は大きくなっ ている。本解析結果の範囲では, 補剛モーメント・水平補剛力は細 長比によらないことが分かる。

部材中央の補剛位置において回転变形が完全に拘束されている場合 文献6)における最小水平補剛剛性 $K_{u 0}$ は, 偏心補剛された $\mathrm{H}$ 形鋼 圧縮部材中央の補剛位置において回転変形が完全に拘束されている 場合の剛性と定義されており，次式のように示される。

$$
K_{u 0}=\frac{3}{2}\left(\frac{\pi}{l}\right)^{4} E I_{y} l
$$

最小水平補剛剛性 $K_{u 0}$ の 1，2，3，4，5，10倍の水平補剛剛 性を有する部材について，数值解析を行った。

図 5 に圧縮部材の細長比入をパラメータとして, 必要補剛力と水

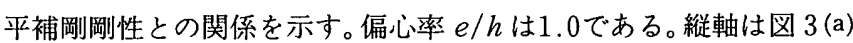
と同様であり,横軸は水平補剛剛性比 $K_{u} / K_{u 0}$ である。圧縮部材の細 長比 $\lambda$ は図 4 と同様である。水平補剛剛性比が大きくなるにつれて 補剛力は小さくなり，一定值に停留していく。補剛力は最大で $3.5 \%$ 程度に達しているものの，概ね $3 \%$ 以下に収まっており，鋼構造限 界耐力設計指針・同解説 ${ }^{11}$ に示されている基準值以下になっている。 

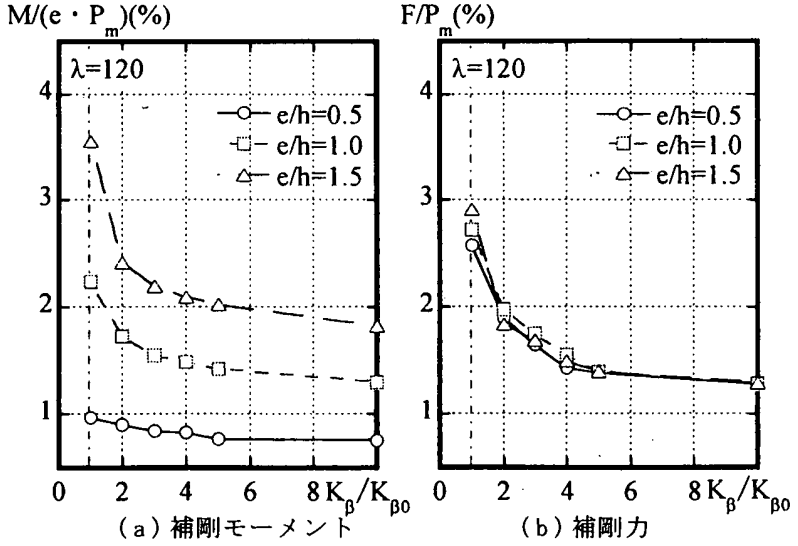

(b) 補剛力

图 3 部材中央で水平変形が完全に拘束されている場合の必要補剛モーメント (偏心率の違い)

また,補剛点において㨝れ変形が完全に拘束されている場合には, 圧縮 部材が(2)式のような㨭れ変形の初期不整を有する場合でも,座屈変形 、は据れを伴わない曲げのみとなり，補剛モーメントはほぼ0であった。

また，図中の曲線は次式に示される通りである。

$$
F / P_{m}=1+\frac{2}{k}
$$

ここで, $k$ は水平補風剛性比 $K_{u} / K_{u 0}$ である。(5)式は必要最小水平 補剛剛性時 $(k=1)$ に, 鋼構造限界状態設計指針・同解説で提示さ れている設計補剛力 $3 \%$ を基点として，水平補剛剛性比の増加に伴 い，数値解析結果の上限となるように，かつ簡便となるように設定 した近似式である。(5)式により水平補剛力と水平補剛剛性との関係 が概ね示されている。

\section{任意の必要水平剛性及び必要回転剛性の組み合わせの場合}

図 6 (a)は水平補剛剛性と回転補剛剛性の組み合わせで必要補剛剛 性となる場合について, 圧縮部材の必要補剛モーメントと回転補剛 岡性との関係を示している。任意の水平補剛剛性と回転補剛剛性の 組み合わせによる必要補剛剛性は, 文献6)より次式のように示される。

$$
\frac{\left(K_{u}-K_{u 0}\right)}{\left(E I_{y} / l^{3}\right)} \frac{\left(K_{\beta}-K_{\beta 0}\right)}{(G K / d)}=\frac{1.0 \times 10^{3}(e / h)^{2}}{(\lambda / \Lambda)^{3}}
$$

偏心量 $e / h=0.5 \sim 1.5$, 圧縮部材細長比 $\lambda=90 \sim 180$ について，(6) 式を満たす $K_{u}, K_{\beta}$ の組み合わせを選び, 解析を行っている。先に述 べたように, 補剛点の回転が完全に拘束されている場合, $K_{u}=K_{u 0}$ であり,補剛点の水平変形が完全に拘束されている場合, $K_{\beta}=K_{\beta 0}$ で ある。各軸は図 3 と同様である。回転補剛剛性の增加に伴い, 補剛 モーメントは增大しており, 図3の傾向と異なっている。図 3 では 補剛点における水平変形を固定しており, 水平補剛剛性は一定值 (無 限大）であるため, 回転補剛剛性の増加は, 単純に補剛剛性全体の 增加を意味することから, 補剛モーメントは低下する。しかし，(6) 式において, 水平補剛剛性 $K_{u}$ 及び回転補剛剛性 $K_{\beta}$ から最小必要補 剛剛性 $K_{u 0}$ 及び $K_{\beta 0}$ を引いた両者の積は一定であるため, 回転補剛 剛性を大きくすると, 必要水平補剛剛性は小さくなっていく。その ため, 図 3 (a)と異なり, 回転補剛剛性の増加とともに, 補剛モーメ ントが増加している。必要補剛モーメント比は $e / h=0.5 て ゙$ 最大 $1.5 \%, e / h=1.0 て ゙ 3.0 \%, e / h=1.5$ で6.0\%程度になっている。

図 6 (b)は任意の水平補剛剛性と回転補剛㴊性の組み合わせで必要 補岡岡性となる場合について, 圧縮部材の必要補剛力と水平補剛岡
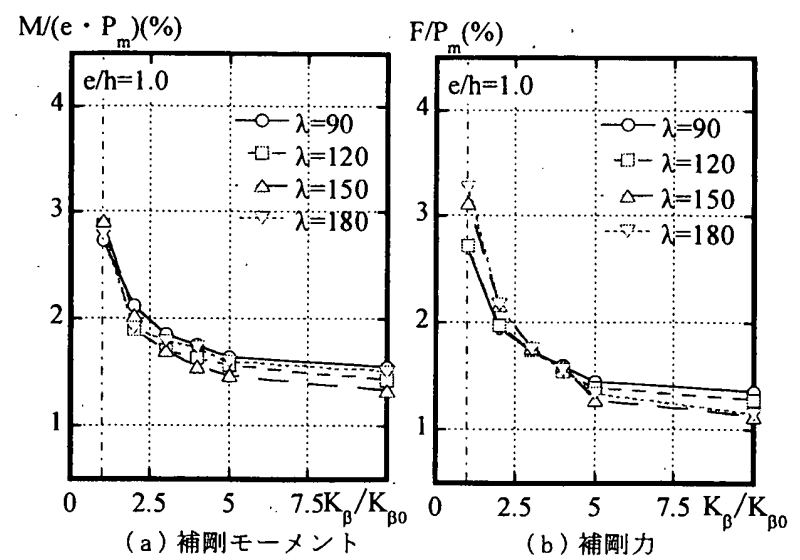

図 4 部材中央で水平変形が完全に拘束されている場合の必要補剛モーメント (細長比の違い)

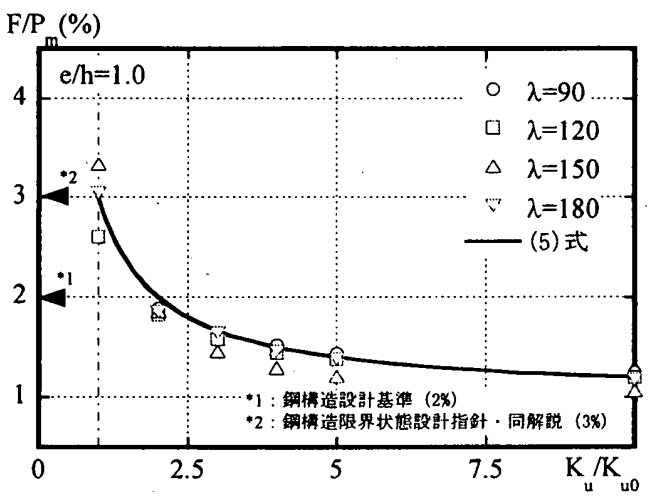

図 5 部材中央で捱れ変形が完全に拘束されている場合の補剛力(細長比の違い)

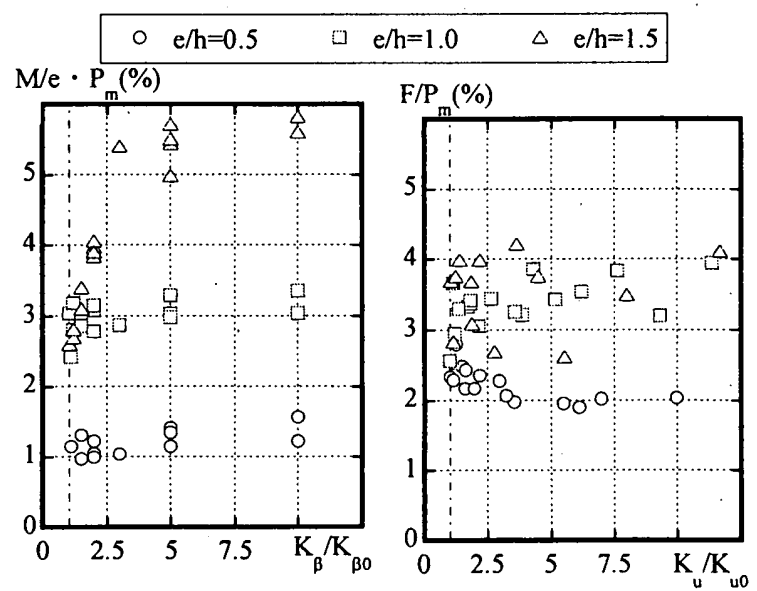

(a) 補剛モーメント

(b) 水平補㓮力

図 6 必要最小補剛剛性によって補剛された場合の補剛水平力・補剛モーメント

性との関係を示している。必要補剛力の下限值を鋼構造座屈設計指 針では $2 \%$, 限界状態設計指針では $3 \%$ と規定しているが, 補剛材 の剛性が(6)式を満たす必要補剛剛性である場合, 補剛力は $e / h=$ 0.5 で $2 \%$ 程度, $e / h=1.5$ で $4 \%$ 程度に達しており; 偏心補剛材に は設計指針で示されている值よりも大きな補剛力を必要とする。

図 7 は偏心量と補剛力・補剛モーメントの関係を示している。(6) 式を満たす任意の水平補剛剛性 $K_{u}$ と回転補剛剛性 $K_{\beta}$ の組み合わ せである必要補剛剛性を基にして, 補剛剛性の違いが補剛力・補剛 
モーメントに与える影響を検討している。縦軸は水平補剛力比 $F / P_{m}$ と, 補剛モーメント比 $M /\left(e \cdot P_{m}\right)$ の和 $F / P_{m}+M /\left(e \cdot P_{m}\right)$ であり, 横軸は偏心率 $e / h$ である。図中の曲線は, (5)式を基に数值解析結果 である各プロットから最小二乗法により得られた近似式であり，次 式に示す通りである。

$$
F / P_{m}+M /\left(e \cdot P_{m}\right)=\left(1+\frac{2}{k^{\prime}}\right)\left[1+\frac{1}{3}\left(\frac{e}{h}\right)+\frac{2}{3}\left(\frac{e}{h}\right)^{2}\right]
$$

ここで， $k^{\prime}$ は(6)式を満たす任意の水平補剛剛性 $K_{u}$ と回転補剛剛 性 $K_{\beta}$ の組み合わせによる必要補剛剛性に対する割合を示してい る。すなわち，補剛材が必要補剛剛性を有する場合， $k^{\prime}=1$ である。 $k^{\prime}=2$ は(6)式を满たす水平補剛剛性 $K_{u}$ と回転補剛剛性 $K_{\beta}$ の組み 合わせとなる必要補剛剛性をそれぞれ 2 倍したものであり， $2 K_{u}$ 及 び $2 K_{\beta}$ を示している。また, 補剛点で回転が完全に拘束されている 場合, 必要水平補剛剛性 $K_{u}$ は $K_{u 0}$ となり, 補剛点で回転が完全に拘 束されている場合, 必要水平補剛剛性 $K_{\beta} は K_{\beta 0}$ となる。右辺の第一 項は必要補剛剛性比に関する項であり, 第二項は偏心による回転補 剛の補剛力比の増加率に関する項である。

偏心が無い場合，圧縮部材に㨭れ変形はほとんど生じておらず, 水平力のみが補剛材に作用し, 補剛力比と補剛モーメント比の合計 は $3 \%$ 程度となっている。偏心量が大きくなるにつれて, 水平補剛 力比と補剛モーメント比の合計は上昇し, $e / h=1.0 て ゙ 6 \% に$ 達す る。例之ば $e / h=1.00$ 場合, 図 6 (b) で補剛モーメント比は 2 ～3\%, 図6(a)で水平補剛力比は $3 \sim 4 \%$, 合計でほほ $6 \%$ とな ることから，概ね(7)式の值に等しくなっている。

\section{3. 偏心補剛された $H$ 形鋼圧縮部材の弾塑性座屈性状}

本章では, 部材中央で偏心補剛された $\mathrm{H}$ 形鋼部材の圧縮載荷実験 を行い, その座屈性状を検討するとともに, 水平補剛力及び補剛モ一 メントを把握する。

\section{1 偏心補剛された $\mathrm{H}$ 形銅圧縮実験及び数值解析概要}

表 1 に本論文で行った試験体の一覧を示す。圧縮部材は $\mathrm{H}-200 \times$ $100 \times 5.5 \times 8$ である。試験体名における最初のアルファベットは補 剛材形状であり，A は角形鋼 $60 \times 60 \times 3.2, \mathrm{~B}$ は角形鋼 $50 \times 50 \times 3.2$, $\mathrm{C}$ は溝形鋼 $100 \times 50 \times 20 \times 3.2, \mathrm{~N}$ は無補剛を示している。次の数字

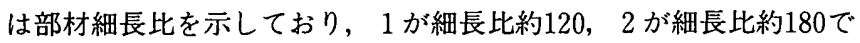
ある。また，(3)，(4)式の必要最小補剛剛性に対する補剛材の軸剛性 比, 曲げ剛性比も併せて示している。本実験では圧縮部材に直交し て補剛材が取り付く場合を想定しているが, 必要最小剛性に对して 10１00倍程度となっている。補剛材を有する試験体の補剛材材長 $a$ は全てにおいて $1840 \mathrm{~mm}$ ，偏心距離 $e$ は $200 \mathrm{~mm}$ である。

表 2 に本実験における試験体の引張試験結果を示す。H 形鋼は SN400A，角形鋼はSTKR400，溝形鋼はSSC400である。

図 8 に本実験の装置の概要を示す。(a)は装置平面図，(b)は試験体 中央における断面図，(c)は装置立面図である。載荷は100ton オイル ジャッキにより部材の一方から行い，装置に取り付いた梁が反力を 受ける。また, 圧縮部材の材端支持条件は強軸回りの回転及び㨝れ. 反りを固定, $\mathrm{H}$ 形鋼弱軸回りの回転のみピン支持となるように, 回 転機構を有する装置をオイルジャッキ，反力梁に取り付けている。 また，(d)，(e)は試験体両材端に取り付けたピン支持装置の詳細であ る。

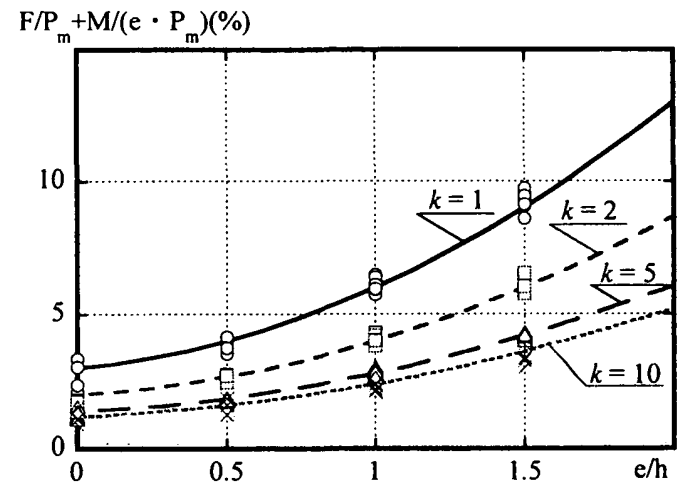

図7偏心率・補剛剛性の違いが必要補剛耐力に及ばす影響

オイルジャッキからの圧縮荷重は，(d)のピンからのせん断力によ り試験体に伝達される。試験体の弱軸回りの回転中心はピンの中心 (試験体の端部)である。本章では, 載荷実験により偏心補剛された 圧縮部材の座屈挙動及び補剛材に作用する補剛力・補剛モーメント の把握を目的としているため，圧縮部材には荷重不整ができるだけ 生じないように芯の調整を行うとともに, $\mathrm{H}$ 形鋼製作時に生じた形 状初期不整以外は特に与えていない。

補剛材の材端支持条件は，全方向変位及び材軸回りの回転を拘束 する 2 方向ピン支持である。また，載荷時の圧縮部材の軸方向変形 に伴う補剛材への作用曲げモーメントの発生を抑えるために, 補剛 材両端部において圧縮部材軸方向に降伏変位程度 $(4 \mathrm{~mm})$ のクリアラ ンスを設けている。圧縮部材の座屈発生, 補剛材への作用軸力及び曲 げモーメントを調べるために, 図 8 (c)に示すよjに圧縮部材, 補剛材 の上下フランジに材軸方向に沿って数箇所歪ゲージを貼付している。

また，数值解析モデルは，圧縮部材については図 1 と同じである が, 補剛材については実験と同様の補剛形式とするために，バネ要 素の代わりに圧縮部材と直交する二節点梁要素としている。本章の 数值解析では，実験と同じ補剛形式において，偏心量，細長比のパ ラメータに対する座屈性状及び補剛軸力・補剛曲げモーメントの把 握を目的としている。荷重初期の歪分布や載荷後の最終変形状態を 元にして，初期不整は(1)式の代わりに, $\sin$ 半波と $\sin$ 一波の合成波 である(8)式，及び(2)式としている。

表 1 試験体リスト

\begin{tabular}{|c|c|c|c|c|c|}
\hline \multirow{2}{*}{ 試験体名 } & \multicolumn{2}{|c|}{ 主材 } & 補剛材 & \multirow{2}{*}{ 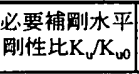 } & \multirow{2}{*}{$\begin{array}{l}\text { 必要補㓮曲げ } \\
\text { 哃性比 } \mathrm{K}_{\beta} / \mathrm{K}_{\beta 0}\end{array}$} \\
\hline & $l(\mathrm{~mm})$ & $\lambda(=/ / i)$ & Section & & \\
\hline A-I & \multirow{4}{*}{2688} & \multirow{4}{*}{118.9} & $\square-60 \times 60 \times 3.2$ & 39.39 & 5.53 \\
\hline B-1 & & & $\square-50 \times 50 \times 3.2$ & 32.46 & 3.10 \\
\hline $\mathrm{C}-1$ & & & C- $100 \times 50 \times 20 \times 3.2$ & 35.92 & 16.7 \\
\hline $\mathrm{N}-1$ & & & - & - & - \\
\hline A-2 & 4032 & 178.3 & $\square .60 \times 60 \times 3.2$ & 132.9 & 20.0 \\
\hline
\end{tabular}

主材断面 $\mathrm{H} 200 \times 100 \times 5.5 \times 8$, 補剛材材長 $a=1840 \mathrm{~mm}$, 偏心距㒕 $=200 \mathrm{~mm}$

表 2 鋼材の機械的性質

\begin{tabular}{|c|c|c|c|c|c|c|c|c|}
\hline \multirow{2}{*}{\multicolumn{2}{|c|}{ TEST PIECE }} & \multirow{2}{*}{ 鋼種 } & \multirow[b]{2}{*}{$\left(\mathrm{kN} / \mathrm{mm}^{2}\right)$} & \multirow{2}{*}{$\frac{\sigma_{y}}{\left(\mathrm{~N} / \mathrm{mm}^{2}\right)}$} & \multirow{2}{*}{$\frac{\sigma_{\mathrm{u}}}{\left(\mathrm{N} / \mathrm{mm}^{2}\right)}$} & \multirow{2}{*}{$\begin{array}{c}\varepsilon_{y} \\
(\%)\end{array}$} & \multirow{2}{*}{$\frac{\varepsilon_{s 1}}{(\%)}$} & \multirow{2}{*}{$\frac{E_{\mathrm{st}}}{\left(\mathrm{N} / \mathrm{mm}^{2}\right)}$} \\
\hline & & & & & & & & \\
\hline $\mathrm{H}-200 \times 100$ & web & SN400A & 207 & 317 & 454 & 0.153 & 2.07 & 2400 \\
\hline$\times 5.5 \times 8$ & frange & SN400A & 209 & 320 & 459 & 0.153 & 2.04 & 2540 \\
\hline \multicolumn{2}{|c|}{$\square-60 \times 60 \times 3.2$} & STKR400 & 211 & 436 & 492 & 0.206 & - & 1510 \\
\hline \multicolumn{2}{|c|}{$\square-50 \times 50 \times 3.2$} & STKR400 & 199 & 415 & 491 & 0.209 & - & 2570 \\
\hline \multicolumn{2}{|c|}{$C-100 \times 50 \times 20 \times 3.2$} & SSC 400 & 202 & 334 & 450 & 0.165 & - & 2750 \\
\hline
\end{tabular}

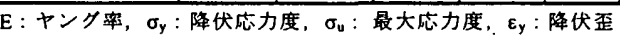

$\varepsilon_{\mathrm{st}}$ : 歪硬化開始時の歪，Est：歪硬化勾配 


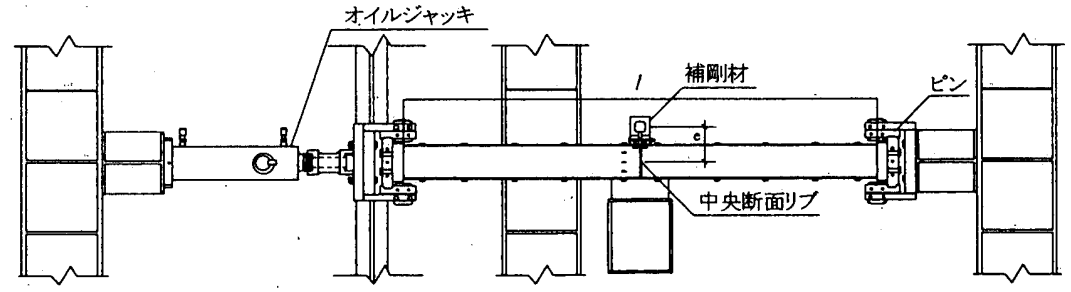

(a) 実験装置立面図

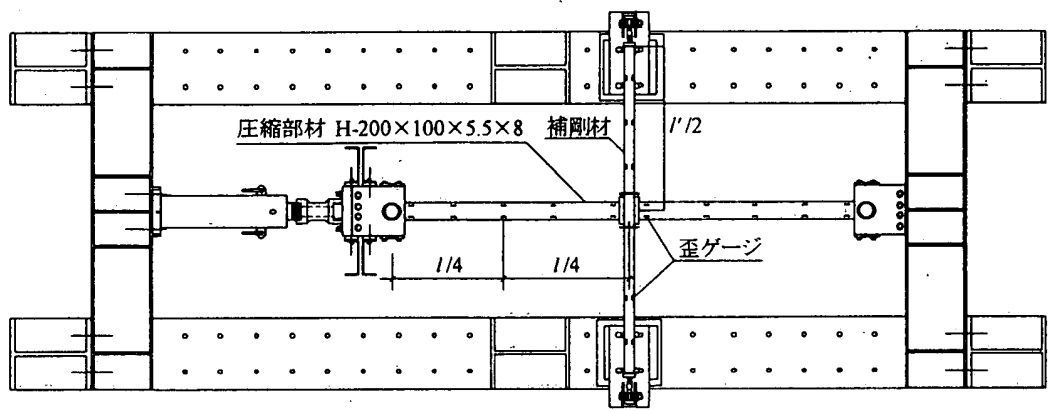

(c) 実験装置平面図

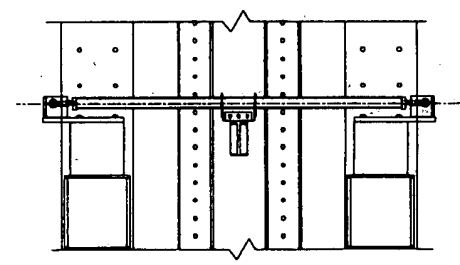

(b) 試験体中央断面図

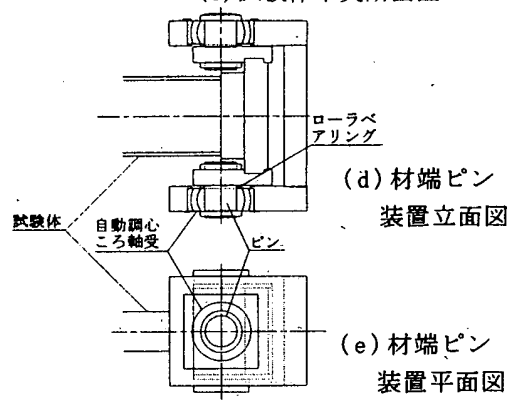

$$
u=l / 1000 \sin \frac{\pi x}{l}+\frac{l}{10000} \sin \frac{2 \pi x}{l}
$$

2 章では補剛材に作用する軸力・曲げモーメントが現実的な範囲 で最大となるように初期不整を与えたが，本章では実験結果に対応 するように, 弾性固有值解析結果の $1 \sim 3$ 次モード（1 次：水平変 形 $\sin$ 半波, 2 次: 水平変形 $\sin$ 一波, 3 次: 㨝几変形 $\sin$ 半波) で ある上記の初期不整を与えている。

\section{2 偏心補剛された $\mathrm{H}$ 形鋼圧縮部材の座屈性状}

図 9 は補剛材耐力の異なる $\mathrm{H}$ 形鋼圧縮部材の荷重変形関係を示 している。綐軸は軸圧縮荷重 $P$ を降伏荷重 $P_{y}$ で除しており, 横軸 は加力点の軸変形 $\delta$ を降伏荷重時の軸変形 $\delta_{y}$ で除している。各プ ロットは実験結果であり，各太線は数值解析結果である。無補剛の N-1については, 実験結果及び数值解析で, 初期剛性から最大耐力以 降の耐力劣化域まで対応している。また, 補剛材を有する A-1, B-1 については，A-1で最大酎力に達するまで緩やかな耐力上昇が見ら れるものの, 最大耐力及び劣化勾配は実験結果と数值解析で概ね对 応している。

補剛材が十分な剛性・耐力を有する場合，無補剛の場合と比較し て, 最大耐力は大幅に上昇している。部材細長比 $\lambda$ が限界細長比 $\Lambda$ 程度の部材でも最大耐力は降伏耐力近くまで上昇している。

図10は圧縮部材の軸変位と水平変形関係を示している。水平変形 は圧縮部材の材軸方向 $l / 4, l / 2,3 l / 4$ のうち最大となる位置での変 形である。困中の『は最大耐力時を示している。偏心補剛された圧 縮部材では, 最大耐力直後から急激に水平変形が急激に增加している。

図11は圧縮部材の軸変形と㨝れ変形関係を示している。㨝れ変形 も水平変形と同様, 圧縮部材中央での変形である。無補剛の N-1は 最大耐力以降も㨭れ変形をほとんど生じていない。偏心補剛された A-1，B-1は最大耐力に達する前に㨝れ変形が徐々に生じている。A

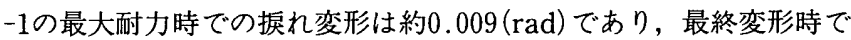
の据れ変形は約 $0.04(\mathrm{rad})$ であった。

写真 1 は載荷後の試験体の変形状態を示している。無補岡の N-1 は部材中央で, 偏心補剛された A-1は試験体材端部と補剛材との補

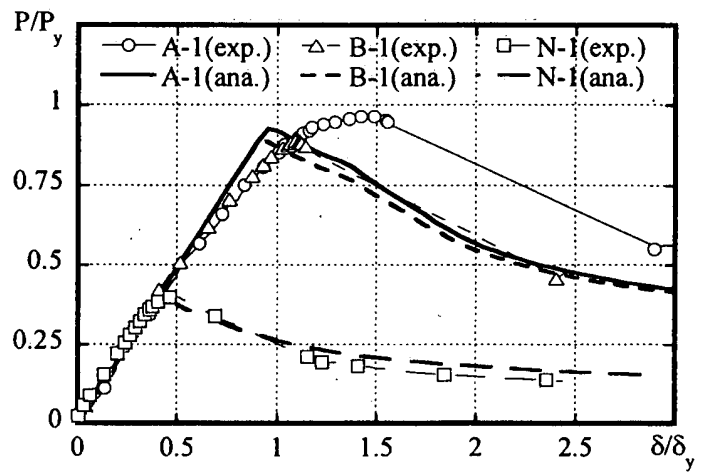

図 9 補剛材耐力の異なる $\mathrm{H}$ 形鋼圧縮部材の軸圧縮荷重一軸変形関保

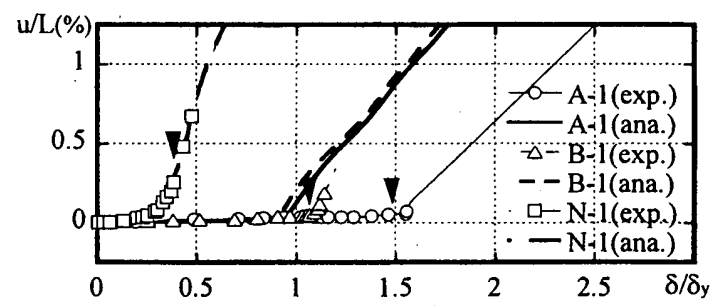

図10補剛材耐力の異なる $\mathrm{H}$ 形鋼圧縮部材の軸変形一水平変形関係

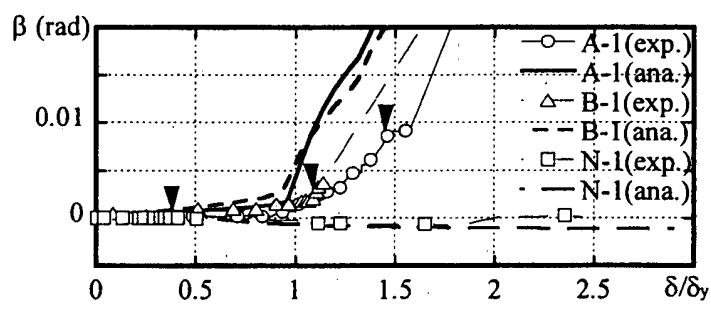

図11補剛材形状の異なる $\mathrm{H}$ 形鋼圧縮部材の軸変形一ねじれ変形関係

，剛区間で座屈変形を生じている。偏心補剛された圧縮部材は，無補 剛の圧縮部材では生じなかった㹉れ変形を生じるが, 水平変形に対 して㨝れ変形は非常に小さい。 


\section{3 圧縮部材及び偏心補剛材の剛性・偏心量の違いが補剛軸力・補} 剛曲げモーメントに与える影響

図12は補剛材に作用している軸力分布と曲げモーメント分布を示 している。(a)は軸力分布であり，(b)は曲げモーメント分布である。 各プロットは実験結果, 各線は数值解析結果を示している。縦軸は 補剛材位置を補剛材の材長で除したものであり，横軸は(a)では水平 補剛力比 $F / P_{m}$ ，(b)では補剛モーメント比 $M /\left(e \cdot P_{m}\right)$ である。それ ぞれ圧縮部材の荷重 $P$ が降伏荷重 $P_{y}$ の0.5，0.75そして最大荷重 $P_{m}$ のときの值である。

図13は補剛材に作用する軸力・曲げモーメントと圧縮部材の軸圧 縮荷重との関係を示している。各プロットは実験結果, 各線は解析 結果である。横軸はそれぞれ図 6 と同様である。圧縮部材の最大耐 力時の水平補剛力及び補剛モーメントは, 実験結果と数值解析結果 で概ね対応している。また, 実験では圧縮部材の最大耐力以降, 急 激に荷重が低下したため，荷重が停留するまでの間，測定があまり

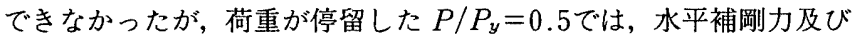

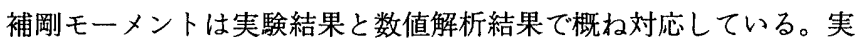
験及び数値解析では, 圧縮部材の降伏軸変形 $\delta_{y}$ の 3 倍まで加力し たものの，水平補剛力及び補剛モーメントは減少することがなかっ た。水平補剛力及 $ひ ゙$ 補剛モーメントは, 主材の最大耐力時で $0.3 \sim 0.4 \%$ ，最終変形時 $\delta / \delta_{y}=3$ で2.5 3\%に達している。

図14は A-1と同様の補剛材断面及び偏心率を有する場合に圧縮 部材の細長比の違いと, 水平補剛力及び補剛モーメントとの関係を 示している。初期勾配は細長比の違いによらずほぼ等しいため, 圧 縮部材の最大耐力時の水平補剛力及び補剛モーメントは圧縮部材の 最大耐力に比例している。また, 最終変形時 $\delta / \delta_{y}=3$ で細長比の小 さいものほど, 水平補剛力及び補剛モーメントは大きくなっている。

図15はA-1と同様の補剛材断面及び細長比の等しい場合に偏心 率と, 水平補剛力及び補剛モーメントとの関係を示している。補剛 力の初期勾配は偏心率の違いによらずほぼ等しく, 圧縮部材の最大 耐力時の水平補剛力は偏心率によらずほぼ等しい。また, 最大耐力 以降の水平補剛力も偏心率による違いはあまりない。しかし, 補剛

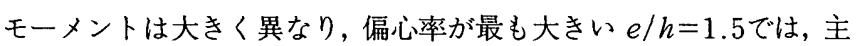
材の最大耐力時で $0.6 \%$, 最終変形時 $\delta / \delta_{y}=3$ で $4.5 \%$ 達している。

表 3 は本実験結果を示している。左から圧縮部材の最大耐力, 水

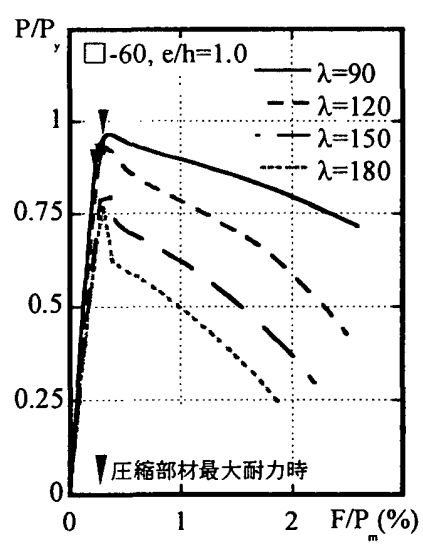

(a) 補剛力

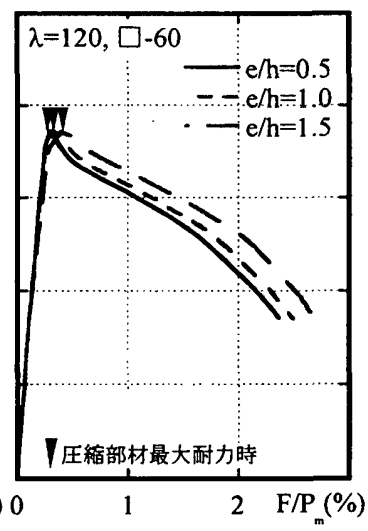

(b) 補甽モーメント
図14 細長比の異なる $\mathrm{H}$ 形鋼圧縮部材の補剛力・補剛モーメント

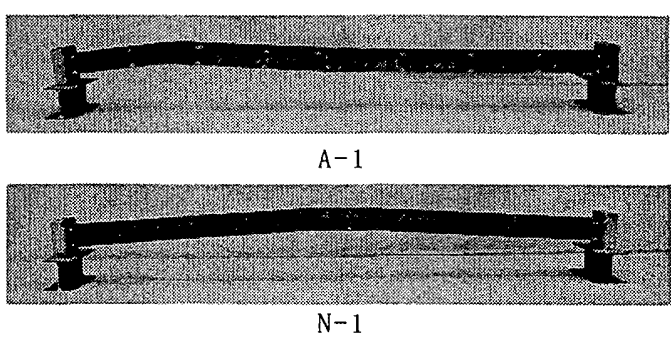

写真 1 最終変形性状
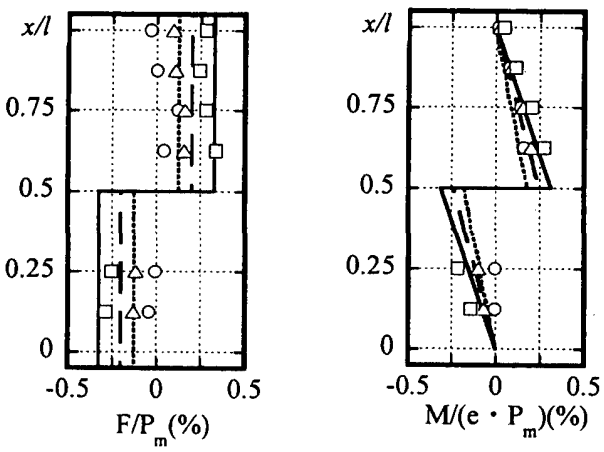

(a) 軸力分布

(b) 曲げモーメント分布

図12 補剛材への作用軸力・モーメント分布

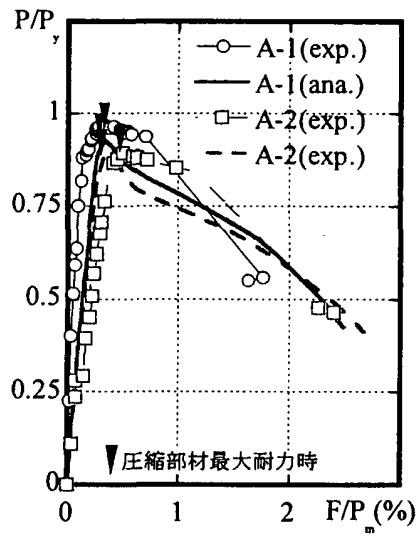

(a) 補剛力

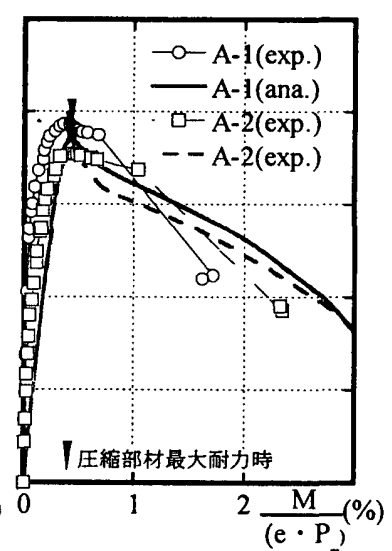

(b) 補剛モーメント
図13補岡材断面の異なる $\mathrm{H}$ 形鋼圧縮部材の補剛力・補剛モーメント
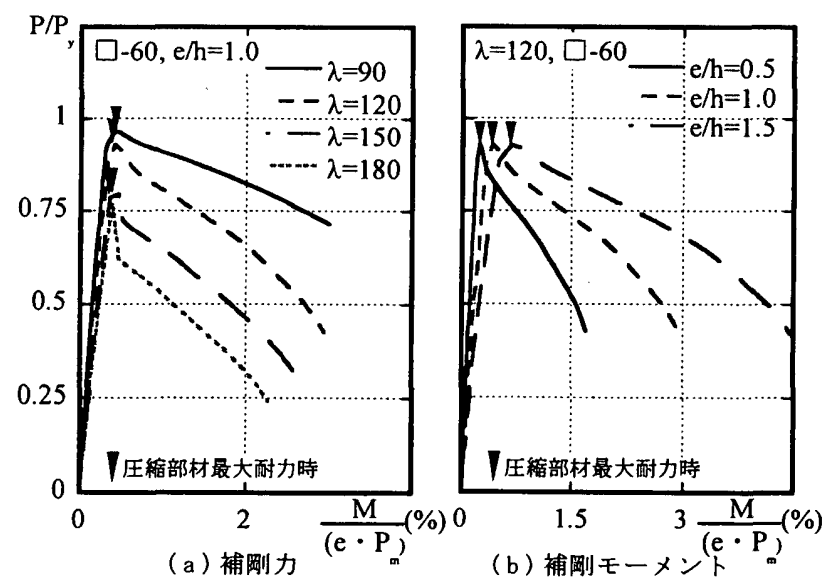

図15 偏心率の異なる $\mathrm{H}$ 形鋼圧縮部材の補剛力・補剛モーメント 
表 3 偏心補剛を受ける.H 形鋼圧縮部材の実験結果

\begin{tabular}{|c|c|c|c|c|c|c|c|c|c|}
\hline \multirow{2}{*}{ 試験体 } & \multicolumn{3}{|c|}{ 圧維部材最大耐力及び有効細長比 } & \multicolumn{2}{|c|}{ 補㓮力 } & \multicolumn{2}{|c|}{ 補㓮曲げモーメント } & \multirow{2}{*}{$\begin{array}{c}\text { 実験結果 } \\
F / \mathrm{P}_{\mathrm{m}}+\mathrm{M} /\left(\mathrm{P}_{\mathrm{m}} \cdot \mathrm{e}\right)(\%) \\
\end{array}$} & \multirow{2}{*}{$\begin{array}{c}(7) \text { 式 } \\
F / P_{m}+M\left(P_{m} \cdot e\right)(\%)\end{array}$} \\
\hline & $\mathrm{P}_{\max }(\mathrm{N})$ & $\mathrm{P}_{\text {max }} / \mathrm{P}_{y}$ & $\lambda_{k}$ & $\mathrm{~F}(\mathrm{~N})$ & $\mathrm{F} / \mathrm{P}_{\mathrm{m}}(\%)$ & $\mathrm{M}(\mathrm{N} \cdot \mathrm{m})$ & $\mathrm{M}\left(\mathrm{P}_{\mathrm{m}} \cdot \mathrm{e}\right)(\%)$ & & \\
\hline$A-1$ & 834 & 0.946 & 37.9 & 3.33 & 0.385 & 716 & 0.413 & 0.798 & 2.18 \\
\hline B-1 & 775 & 0.892 & 53.7 & 4.11 & 0.472 & 610 & 0.351 & 0.823 & 2.32 \\
\hline $\mathrm{C}-1$ & 797 & 0.907 & 49.7 & 2.09 & 0.238 & 557 & 0.317 & 0.554 & 2.06 \\
\hline $\mathrm{N}-1$ & 353 & 0.400 & 126 & - & - & - & - & - & - \\
\hline $\mathrm{A}-2$ & 670 & 0.756 & 80.6 & 1.92 & 0.217 & 583 & 0.329 & 0.546 & 2.05 \\
\hline
\end{tabular}

$$
\lambda_{k}=\sqrt{\frac{\left(1-P_{\max } / P_{y}\right) \Lambda^{2}}{0.4}}\left(\lambda_{k}<\Lambda\right) \quad(9), \quad \lambda_{k}=\sqrt{\frac{\pi^{2} E}{\sigma_{y}}\left(\frac{P_{y}}{P_{\max }}\right)}\left(\lambda_{k} \geq \Lambda\right)
$$

平補剛力, 補剛モーメントである。ここで, 水平補剛力及び補剛モー メントは圧縮部材の最大荷重時の值である。また, 補剛モーメント については補剛材の計測した位置 $(x / l=0.625)$ から補剛材中央で の值に換算している。有効細長比 $\lambda_{k}$ は表 3 下の(9), (10)式より求めら れる。压縮部材最大荷重時の水平補剛力は，最大でも圧縮部材降伏 軸力の約 $0.5 \%$ 程度であり, 現行の設計指針 ${ }^{11}$ に示されている $2 \%$ を 大きく下回っている。また, 補剛モーメントは, 最大荷重に偏心距 離を乗じた值の最大で約 $0.4 \%$ 程度であり, 水平補剛力とほぼ同程度 となっている。実験にお什る水平補剛力と補剛モーメントの和と(7) 式の值を比較すると, 実験結果は(7)式の $1 / 3 \sim 1 / 4$ 程度であり，(7)式 が安全側の評価になることが確認された。両者の違いとしては，2 章では補剛材に発生する補剛力の上限を定めるために，現塞的な範 囲の中で最大の補剛力が発生するように初期不整の形状・大きさを 与之ているのに対して，3 章では偏心補剛された圧縮部材の力学性 状を把握するために， $\mathrm{H}$ 形鋼製作時の初期不整以外は実験時に極力 生じないように配虑した点である。しかし，実際の構造物において 偏心補剛された場合，施工によって生じる荷重不整や形状初期不整 も考えられることから，補剛材に作用する水平力，曲げモ一メント は実験時より大きくなることが予想されるため，必要補剛力・必要 補剛モーメントは，2 章で得られた上限值を用いた方が良い。

\section{4. 結}

本論文では，偏心補剛された中幅 $\mathrm{H}$ 形鋼圧縮部材の必要水平補 剛力・必要補剛曲げ耐力及び弾塑性座屈挙動について把握するため, 実際の单層卜ラス架構で想定される部材細長比 $\lambda=90 \sim 180$, 偏心率 $e / h=0 \sim 1.5 の$ 範囲について検討した。以下に得られた結論を示す。

1) $\mathrm{H}$ 形鋼圧縮部材が偏心補剛され, 補剛点において水平変位が固 定された場合，回転補剛剛性が小さくなるにつれて補剛モーメン トは大きくなる。

2) $\mathrm{H}$ 形鋼圧縮部材が偏心補剛され，補剛点において材軸回りの回 転が固定された場合，水平補剛剛性が小さくなるにつれて，水平 補剛力は大きくなる。

3 ）水平剛性と回転補剛性の任意の組み合わせによる必要補剛剛性 を偏心補剛材が有する場合，水平補剛力は圧縮部材の座屈荷重に 対して, 平均で $3 \%$, 最大で $4 \%$ 程度に達している。これは現行 の座屈設計指針及び鋼構造限界状態設計指針の制限值（それぞれ $2 \% ， 3 \%$ ）を上回っている。

4 ) 水平剛性と回転補剛性の任意の組み合わせによる必要補剛剛性 を偏心補剛材が有する場合, 補剛モーメントは, 補剛材と圧縮部 材の取り付き位置すなわち偏心量による。偏心率が $0.5,1.0,1.5$
の場合，圧縮部材の座屈荷重に偏心量を乗じたものに対して，そ れぞれ最大 $1.5 \% ， 3 \% ， 6.0 \%$ 程度となっている。

5 ) 水平剛性と回転補剛性の任意の組み合わせによる必要補剛剛性 を偏心補剛材が有する場合, 水平補剛力比と補剛モーメント比の 和は，補剛剛性比，偏心率を指標とした(7)式で評価できる。

6 ）偏心補剛材が $\mathrm{H}$ 形鋼部材に直交して取り付く場合の載荷実験 において，H 形鋼圧縮部材の座屈長さは，補剛区間に相当する長 さに低減できる。

7 ）偏心補剛材が $\mathrm{H}$ 形鋼部材に直交して取り付く場合の載荷実験 において，初期不整をできる限り生じないようにした場合，水平 補剛力比及び補剛モーメント比の和は，(7)式で得られる值よりも 小さくなっている。しかし，実際の構造物では施工時に生じる不 整が考之られることから，必要補剛力・必要補剛モーメントは(7) 式で評価する必要がある。

\section{謝 辞}

本研究の一部は平成14年度科学研究費補助金基盤研究(c)(2)（課題 番号14550560）によるものである。また，実験結果については，東 京工業大学大学院生の紺野裕之君の修士論文の成果によるものであ る。関係各位に深く感謝の意を表す。

\section{参考文献}

1）日本建築学会：鋼構造物の座屈に関する諸問題2001 第 1 章 部材座屈 に影響する初期不整の種類と統計的データ，2001.11

2）辻 文三, 西川大介：圧縮材の構造特性に及ほす偏心補剛材の剛性·強度, 銅構造論文集，第 4 巻，第15号，pp63 70，1997.9

3）深尾英邦，森野唗輔：中間に座屈補剛支点を有する圧縮材の弾塑性挙動と 必要補剛性能, 日本建築学会構造系論文集, 第528号, pp151 157, 2000.2

4）深尾英邦, 桑田志都子, 森野捷輔, 川口 淳：中間に弾性補剛ばねを持つ 圧縮材の弾塑性挙動に関する実験的研究, 日本建築学会構造系論文集, 第 530 号, pp171 176, 2000.4

5）黑岩義彦，木村祥裕，正岡典夫，小河利行，加藤史郎：単層卜ラ又架構の 接合継手簡略化に関する研究 换り加工を施した $\mathrm{H}$ 形鎆部材，鋼構造論 文集，第10巻，第38号，pp51 60，2003.6

6）木村祥裕, 小河利行：偏心補剛された $\mathrm{H}$ 形鋼圧縮部材の座屈荷重と必要 補剛剛性，日本建築学会構造系論文集，第574号，pp213 218，2003.12

7) ABAQUS/Standard User's Manual version 5.8

8）青木徽彦,福本 士：鋼柱の座屈強度のばらつきにおよはす残留応力分布 の影響について，第370号，pp19 27, 1986.12

9）小野徽郎，石田交広，下野耕一：限界状態を考虑した鋼構造圧縮部材及び 曲げ材の補剛に関する研究，日本建築学会構造系論文集，第469号， pp117 125, 1995.3

10）日本建築学会：鋼構造座屈設計指針・同解説，1996

11）日本建築学会：鋼構造限界状態設計指針・同解説，1998

（2004年 4 月 10 日原稿受理，2004年 8 月 12 日採用決定） 